\title{
Local Peace Committees and Grassroots Peacebuilding in Africa
}

\author{
Fritz Nganje
}

\section{INTRODUCTION}

This chapter analyzes the role of local peace committees (LPCs) as mechanisms for microlevel peacebuilding in Africa. Since the end of the Cold War, LPCs have been used globally as mechanisms to promote sustainable peace, against the backdrop of changing conflict dynamics and a new peacebuilding discourse that valorized the local context, local initiatives, and local agency in peacebuilding processes. The so-called "local turn" in peacebuilding inspired support for diverse forms of grassroots peacebuilding initiatives, not least in Africa, which have generally been identified with the generic term of "local peace committees." In taking stock of the practices and evolution of LPCs in Africa over the past 30 years, this chapter seeks to highlight the key issues that have animated

F. Nganje $(\bowtie)$

Department of Politics and International Relations,

University of Johannesburg, Johannesburg, South Africa

e-mail: fnganje@uj.ac.za

(C) The Author(s) 2021

T. McNamee and M. Muyangwa (eds.),

The State of Peacebuilding in Africa, https://doi.org/10.1007/978-3-030-46636-7_8 
grassroots peacebuilding during this period, while also identifying valuable lessons and best practices that could form the basis for improving this approach to peacebuilding in Africa.

The chapter is structured in four sections. The first section provides an overview of the peacebuilding the role of LPCs in Africa over the past three decades, coinciding with the ascendancy and evolution of the global discourse on "peacebuilding from below." The second section identifies and analyzes some of the key issues, lessons, and best practices that stand out from 30 years of grassroots peacebuilding through a variety of LPCs. The third and final section offers three policy recommendations for unlocking the full potential of LPCs.

\section{Evolution of local Peace Committees as Mechanisms for Grassroots Peacebuilding in Africa}

Local peace committee is a generic name for a variety of local structures established for purposes of peacemaking and peacebuilding, using both traditional and modern conflict resolution mechanisms. LPCs are envisioned as organic, inclusive, participatory, and non-threatening social spaces that facilitate dialogue and mutual understanding, and allow for constructive problem-solving and joint action to prevent violence. ${ }^{l}$ They have, therefore, been described as instruments that strengthen social cohesion and the resilience of local communities, thereby contributing to the search for sustainable peace beyond the immediate local environment. ${ }^{2}$ Local peace committees are founded on the premise that individuals in communities affected by violent conflict have greater incentives than any external actor to resolve such conflict. They are also thought to be better placed to build and sustain peace through their intimate knowledge of the local culture, as well as community relations and dynamics. In this regard, the concept of LPCs resonates with the "peacebuilding from below" discourse, which gained prominence in the 1990s and argued for local communities affected by violent conflict to be recognized as resources and not just recipients of peacebuilding efforts that are largely driven from the outside. ${ }^{3}$ 


\section{Emergence of Local Peace Committees in Africa as Self-Help Community Initiatives}

In Africa, "local peace" committees arose as mechanisms for grassroots peacebuilding in the 1990s when local communities affected by violent conflict resorted to diverse self-help structures to facilitate dialogue, manage conflict and promote peaceful coexistence. Local peace committees in this context were essentially self-organizing community initiatives that emerged organically to fill the void left by national and international peacebuilding efforts, and generally drew on traditional African conflict resolution practices. In Kenya, for example, the Wajir Peace and Development Committee (WPDC) was established in 1995 through the efforts of a small group of women in response to recurrent violent conflict that had virtually crippled life in Wajir County. As Kaitlyn Hedditch noted, this homegrown peace initiative was the last resort to restoring some degree of normalcy in the Wajir district after international actors working to bring peace in the area pulled out following the killing of a United Nations Children's Fund (UNICEF) pilot and aid worker in September 1993. ${ }^{4}$ Although it would eventually engage with district authorities, the Wajir peace initiative originated with and was led by peace crusaders within the conflict-affected communities, who through sensitization campaigns and mediating among clan elders "succeeded in implementing and maintaining peace in the district." 5 The relative success of the Wajir peace committee in arresting the tide of violence in the district inspired the establishment of similar structures in other districts in northern Kenya in the 1990s. Local peace committees also became the preferred mechanism for resolving cross-border disputes along Kenya's borders with Somalia and Ethiopia. ${ }^{6}$

Similar examples of indigenous peacebuilding initiatives were recorded during this period in other African countries, such as Ghana and Burundi. In the case of the former, local peacebuilding initiatives spearheaded by civil society formations, based primarily on a methodology that combined community dialogue, mediation, and reconciliation, were credited with contributing to restoring relative peace and stability in the northern part of the country which had experienced high levels of inter- and intra-communal violent conflict between 1990 and 2002. ${ }^{7}$ 
In Burundi, LPCs emerged in the mid-1990s as informal mechanisms for dialogue, conflict management, reconciliation, and social rehabilitation to complement the official Arusha Peace Process that ended a decade-long civil war. The first of such structures, the Kibimba Peace Committee established in 1994, inspired the formation of LPCs across Burundi by playing an effective role in restoring trust among rival Hutu and Tutsi, and rebuilding the social fabric of a community that had been torn apart by inter-ethnic atrocities during the civil war. ${ }^{8}$

\section{Toward the Formalization of Local Peace Committees in Africa}

Arguably, it was in South Africa that local peace committees were first institutionalized and given a formal mandate to localize a national peace process in an African country. Following the signing of the National Peace Accord (NPA) in 1991 as part of South Africa's political transition, a nationwide network of peace committees was established. Within this framework, LPCs were charged with facilitating dialogue, building tolerance, and addressing issues of conflict through mediation and problemsolving approaches. ${ }^{9}$ Andries Odendaal argued that, thanks in part to their institutionalization and the material and technical support that came with this, LPCs played an important role in mitigating the violent effect that South Africa's volatile transition had on local communities. However, he also observed that as part of a top-down peace process, LPCs did not always enjoy the support of local actors. What is more, their peacebuilding role was constrained by the deep polarization that characterized the transition, and the fact that both the NPA and LPCs were ill-equipped to resolve the greater structural conditions of inequality that caused conflict within the South African society. ${ }^{10}$ As a result of these and other challenges, South Africa's formal LPCs fell into disuse after the country's political transition in $1994 .^{11}$

The trend toward the formalization of LPCs in Africa became more prominent in the first part of the twenty-first century, amidst new and intractable peacebuilding challenges, which had prompted African leaders to adopt a resolution in 2002 requesting African countries to establish national frameworks to prevent, manage, and resolve conflicts. ${ }^{12}$ New thinking within the "peacebuilding from below" discourse, which cautioned against taking for granted the peacebuilding potential of the local context, and questioned the dichotomy often maintained between local, national, and international peacebuilding initiatives, ${ }^{13}$ also 
contributed to efforts at institutionalizing LPCs by giving prominence to ideas such as Infrastructure for Peace (I4P). As a concept, I4P is loosely defined as "a network of interdependent systems, resources, values and skills held by government, civil society, and community institutions that promote dialogue and consultation; prevent conflict and enable peaceful mediation when violence occurs in a society." ${ }^{\prime 4}$ Proponents of I4P argue that it affords local actors and communities the opportunity to "call on political and infrastructural resources at national [and international levels]," while still rooting their peacebuilding initiatives in the relevant local context, history, and culture. ${ }^{15}$ It is, therefore, seen as an alternative peacebuilding approach with the potential to transform the power dynamics inherent in, and harness the positive aspects of, the relationship between local, state, and international actors.

Ghana is the first African country that has in recent years taken steps to recognize, formalize, and incorporate LPCs into a national peace infrastructure. Inspired by the relative success of local peacemaking and peacebuilding processes, the Ghanaian government, with the support of the United Nations Development Programme (UNDP), established a peace architecture in 2005 composed of national, regional, and district peace councils with mandates to facilitate dialogue, problem-solving, and reconciliation processes throughout the country. Peace councils are supported administratively and technically by a Peacebuilding Support Unit within the Ministry of the Interior. Although it is yet to be fully institutionalized, Ghana's national peace architecture is believed to have contributed to defusing political tension during the highly contested 2008 and 2012 elections, and is seen as a model for harnessing local peace processes to promote peace and security at the national level. ${ }^{16}$

In Kenya, early attempts to formalize LPCs can be traced to 2001 when the government established the National Steering Committee on Peacebuilding and Conflict Management, which was tasked with formulating a national conflict management and peacebuilding policy, and coordinating various peacebuilding initiatives, including LPCs. However, it was in the aftermath of the 2007 post-election violence that a concerted effort was made to institutionalize a national peace architecture on the back of existing local peace structures. Odendaal argued that "the fact that districts with peace committees reported much less violence than others considerably raised awareness of the importance of enhancing local capacities for peace." 17 The 2008 National Accord and Reconciliation Agreement that ended the violence recommended the establishment 
of district peace committees throughout the country. With the support of external donors such as the United States Agency for International Development (USAID), peace committees have since been created and capacitated in almost every district in Kenya, and have become key components of an evolving national architecture for peacebuilding and conflict management, albeit with mixed outcomes. ${ }^{18}$

Ethiopia represents a rather unique case of the formalization of LPCs in Africa. Since 2009, LPCs have become an integral part of the state's conflict prevention and resolution mechanism. What is more, LPCs in Ethiopia's border areas that form part of East Africa's Karamoja and Somali clusters have also been integrated into the subregional mechanism for conflict early warning and early response under the auspices of the Intergovernmental Authority on Development (IGAD). IGAD's early warning and early response mechanism relies on the activities of a network of governmental and non-governmental stakeholders in each of its member states, coordinated by national Conflict Early Warning and Early Response Units (CEWERU). In Ethiopia, local peace committees play a significant role in localizing the mandate of the subregional mechanism for preventing, de-escalating, and resolving pastoral and related conflicts along the country's borders with Kenya, Somalia, and South Sudan. LPCs in turn receive financial, technical, and material support from IGAD's Rapid Response Fund. ${ }^{19}$

\section{The Ascendancy of NGO-Sponsored Local Peace Committees}

In those African countries where persistent social conflict has generated a strong need for concerted efforts to capitalize on grassroots mechanisms for peacebuilding and social cohesion, but there has not been an appetite to institutionalize these structures, it is often local and international NGOs that have stepped in to support and, in some instances, create LPCs. This is the case in Burundi where despite the relative successes of LPCs in restoring the social fabric of communities in the war-torn country, local peace processes have unfolded without governmental support or an overarching peace architecture. Instead, it is national and international NGOs, such as the Ministry for Peace and Reconciliation Under the Cross (MI-PAREC) and the British-based Agency for Cooperation and Research in Development (ACORD), that have been instrumental in creating and supporting LPCs as part of their peacebuilding and reconciliation strategies in the country. ${ }^{20}$ Inspired by the 
first LPC established by the residents of Kibimba in 1994, it is estimated that by 2012 NGOs had established and were supporting about 450 local peace committees in over 30 percent of the communes in Burundi. ${ }^{21}$

A similar trend can be observed in South Africa against the backdrop of increasing violence and social unrest in the country's impoverished townships and informal urban settlements, including xenophobic intolerance against migrants from other African countries. For example, in response to the large-scale xenophobic violence that killed more than 60 people in major urban areas across South Africa in 2008, the Action Support Centre (ASC), a Johannesburg-based NGO, launched an initiative in 2010 to harness the positive legacy of LPCs that were created during South Africa's transition but had since become defunct. The ASC has worked to revive LPCs in major hotspots of xenophobic conflict in townships and impoverished suburbs around Johannesburg, Pretoria, and Durban. It provides continued technical, logistical, and moral support to LPCs, mostly in the form of training in mediation and conflict transformation, but also through initiatives such as the Local Peacebuilders Awards, which recognize individual and community efforts dedicated to promoting peace and social cohesion in these townships and suburbs. ${ }^{22}$ Local peace committees in this context have used a combination of community dialogues, mediation, as well as education and awareness campaigns to attempt to resolve differences and foster mutual understanding and reconciliation between foreign nationals and their South African hosts. ${ }^{23}$ They have also reportedly been instrumental in arresting the spread of violence during the recent 2019-2020 episodes of xenophobic unrest, playing a major role in alerting the police and other relevant authorities to potential attacks, and mobilizing communities to protect foreign nationals and their properties. ${ }^{24}$

\section{Three Decades of Local Peace Committees: Key Issues AND LESSONS LEARNED}

For the purpose of highlighting pertinent lessons that could assist in strengthening local peacebuilding processes on the continent, this section identifies and discusses five key issues and best practices that stand out from the preceding review of the peacebuilding role of LPCs in Africa. These relate to the formalization, or lack thereof, of LPCs; their relationship with formal institutions and processes of governance; the scope of 
intervention of; contradictions in the peacebuilding role of LPCs, as well as the issue of external funding and support.

\section{To Formalize or Not to Formalize?}

Perhaps the major issue that has defined the peacebuilding role of LPCs in Africa is how to reconcile the dilemma: between retaining the essentially informal character of these structures and reaping the benefits that come with formalization. As pointed out earlier, the value proposition of the notion of local peace committee rests primarily on the argument that peacebuilding initiatives that are anchored in the resources and everyday experiences of local communities, as opposed to being externally imposed, have a greater chance of success and sustainability. The relative success of pioneering LPCs in countries like Kenya, Ghana, and Burundi has, therefore, been attributed largely to their informality, which encouraged dynamism in, as well as local participation and ownership of, peacebuilding processes. Informality also means that the work of LPCs is not hamstrung by the politicking that often undermines the effectiveness and efficiency of formal peacebuilding processes.

However, as the South African case suggests, informality can also pose a challenge to the effectiveness of LPCs. In the post-apartheid period, LPCs operating as informal community structures have been constrained in their peacebuilding role by their lack of institutional legitimacy and the corresponding inability to influence the formal processes of governance. Local peace committees in this context have also received little support and cooperation from state agencies, making it difficult for them to effectively address local conflicts that are embedded in the broader political, social, and economic structure of the state. The present situation contrasts with the experience of LPCs that operated in South Africa in the 1990s. Because these earlier structures were institutionalized as part of a national peace architecture, and were endowed with a formal mandate to localize the transitional peace process, they had access to material, technical, and institutional support from the state. This formalization was crucial in empowering LPCs to play an important role in mitigating the violent effect that South Africa's volatile transition had on local communities, even though the top-down nature of the peace process meant that LPCs did not always enjoy the support of local actors. ${ }^{25}$

It is partly in an attempt to reconcile this dilemma that the idea of I4P has gained prominence in discourses on peacebuilding in Africa. National 
and regional peace architectures that have been established in Ghana, Kenya, and other parts of East Africa hold the prospects of "[creating] sufficient space for local leaders to establish structures and processes that suit their situation best and that will enhance their sense of local ownership and achievement... [while allowing] local communities to call on political and infrastructural resources at national [and regional levels]."26 However, the existence of national peace infrastructures is no guarantee that LPCs will have a constructive relationship with the formal institutions and processes of governance.

\section{Relationship with Formal Institutions and Processes of the State}

Whether operating as informal or institutionalized mechanisms, local peace committees cannot escape the influence of formal institutions and processes. The effectiveness of the peacebuilding role of LPCs, therefore, depends to a large extent on the nature and quality of their relationship with the formal institutions and processes of the state. This relationship takes on various forms. Firstly, LPCs often rely on their association with state institutions to legitimize and garner broad support for their peacebuilding activities. However, the involvement of local authorities in the work of LPCs has sometimes had a constraining rather than an enabling effect. Elected officials, in particular, have tended to infiltrate LPCs for purposes of using these structures to promote their narrow political ends. Because LPCs generally lack enforcement capacity and often rely on their moral authority, the absence of a cooperative relationship with local officials and other state agencies such as the police has, in some instances, also undermined the efficacy of their peacebuilding initiatives. In other cases, LPCs have been forced to assume a subordinate and largely ineffective role because their mandate and functions overlap with those of local state structures.

The complementarity between the methods used by LPCs and existing institutional processes is also a key determinant of the peacebuilding effectiveness. For example, in South Africa where a Mozambican national was gruesomely murdered during the wave of xenophobic violence in 2015, the local peace committee in the township of Alexandra was able to complement the formal judicial process of prosecution with a traditional process of forgiveness and healing, which, according to a member of the Alexandra LPC, brought some degree of reconciliation to the affected 
families. A member of the Alexandra local peace committee describes the relationship of their intervention to the formal judicial process as follows:

Two of the families of the boys who killed Sithole [the murdered Mozambican national] wanted to talk to the bereaved family. All the families wanted was to say "sorry," but that process was not allowed because according to our formal justice system the two parties should be separated. I told the families to write a letter expressing their apology which I took to the Sithole family. Sithole's family read the letter and said they forgive them, but the total and true forgiveness will come when the family of Mthethwa [one of the accused] goes to the grave of the deceased and apologises according to our culture. ${ }^{27}$

Where this complementarity is lacking, the tension between the preferred peacebuilding methods of local peace committees and the institutional processes of the state has tended to constrain the role of LPCs. This is the case in Kenya, where the use of customary conflict management and peacebuilding methods by LPCs has sometimes come up against the constitutional values and justice system of the state. ${ }^{28}$ There have been instances where court orders have been used to challenge and inhibit the work of LPCs. ${ }^{29}$ A legal and policy framework that clearly defines the role and mandate of LPCs in relation to the formal institutions of the state is, therefore, critical for the effectiveness of these structures.

\section{Scope of Local Peace Committee Intervention}

Another important lesson that stands out from the review of local peace committees in Africa over the past three decades relates to what LPCs can do and what they cannot be expected to achieve. As the cases highlighted above suggest, LPCs are most effective in the context of low-key community conflicts that can be addressed using dialogue, mediation, or other problem-solving approaches. LPCs are generally ill-suited for conflict situations that require the enforcement of peace, as they are often designed to be essentially consensus-building forums. This is particularly true for informal LPCs, which lack institutional legitimacy and depend largely on their moral authority for acceptance in the local environment in which they operate.

Even in cases where LPCs are formalized, it would be naïve to expect them to make any significant contribution to resolving conflicts that are 
rooted in the socio-economic and political structure of the state, especially in the absence of a commitment by the relevant authorities to address the underlying causes of conflict. As Odendaal has observed, "LPCs will not be successful when there is a lack of political will toward peace at national level [and] it cannot be expected of LPCs to address the root causes of conflict, namely the larger political, social, or economic systems." ${ }^{30}$ In this regard, LPCs can play a role in mitigating the effects of violent conflicts in their communities, but are often powerless in transforming the dynamics of the conflict and bringing about sustainable peace.

Likewise, although in countries like South Africa local peace committees have been instrumental in resolving disputes arising from inefficiencies and perceived corruption in the processes of local governance, LPCs cannot be expected to assume the service delivery and community safety functions of local governments for which they have no mandate. They can collaborate with relevant local government structures and facilitate the efficient and equitable delivery of social services, but should, at all times, resist the temptation of taking on local government functions that would dilute their core peacebuilding role.

\section{Local Peace Committees as Sites for Social Contestation and Normative Contradictions}

In principle, LPCs are intended as inclusive and non-threatening social spaces that promote broad stakeholder participation in the common search for peace and harmony. However, a closer look at the history of LPCs on the continent suggests that these same characteristics can be an impediment to micro-level peacebuilding. The imperative for inclusiveness means that LPCs sometimes include local actors who have no vested interest in peace, but see these structures primarily as forums for extending their influence and promoting their narrow political and economic interests.

In this context, LPCs become sites for power struggles between different social interests, often at the expense of efforts to foster peace and social cohesion in the respective communities. In the aftermath of the 2015 xenophobic unrest in major urban areas across South Africa, efforts by the Orange Farm LPC to promote reconciliation between foreign nationals and their South African counterparts were held hostage by political party posturing within the committee. Community dialogues convened by the local peace committee "were marred by political jostling 
by ANC members who refused to allow the meetings to continue unless the ANC branch chairperson facilitated proceedings."31

Moreover, while LPCs draw significant strength and legitimacy from being rooted in the local culture and processes, this local embeddedness also means that they almost invariably replicate the power structures that prevail in the communities in which they operate. Working through, instead of attempting to transform, traditional power structures that are oppressive and discriminatory may enable local peace committees to earn the cooperation of local power brokers, but this compromise has implications for the nature of the peace that LPCs are able to create. For example, Kaitlyn Hedditch noted that accounts of the success of the Wajir peace committee in Kenya often mask "the challenging circumstances through which [the women at the center of the initiative] were forced to both assert and compromise their agency," in an attempt to simultaneously accommodate and challenge traditionally ascribed gender roles. ${ }^{32}$

In South Africa, where a xenophobic attitude is entrenched in the dominant power structure prevailing in townships and informal settlements, some LPCs have tended to embody and reproduce the marginalization of, and discrimination against, migrants from other African countries. For example, the LPC in Orange Farm has been used by local politicians, business people, and other dominant interest groups to informally exercise control over the existence and activities of migrants residing in the township. ${ }^{33}$

These inherent contradictions in the role of LPCs do not only undermine their peacebuilding effectiveness, but also raise questions about their accountability. LPCs often lack formal accountability mechanisms, and tend to rely on the principles of inclusiveness, participation, and transparency to safeguard the integrity of their activities and outcomes. The restraining effect of these principles is sometimes trumped by contending norms and unequal power relations in the local communities in which LPCs are embedded.

\section{Funding and External Support}

The issue of funding and external support has been a contentious theme in the evolution of LPCs as peacebuilding mechanisms in Africa. Although many LPCs in Africa started their work relying almost exclusively on community resources, they have tended to depend on external support to sustain their peacebuilding activities. Financial, technical, institutional, or 
even moral support for LPCs in Africa has come from local and national governments, donor agencies like USAID, intergovernmental and multilateral development organizations such as IGAD and the UNDP, as well as a variety of international and local NGOs.

Historically, external support for LPCs in Africa has produced mixed outcomes. On the one hand, some LPCs established by NGOs have become so dependent on external funding and support that they have been unable to operate on their own. Similarly, it has been reported that in countries like Kenya and Liberia where NGOs have paid so-called "sitting fees" to peace monitors, this has destroyed the spirit of volunteerism and undermined the very essence of local peace committees as community-inspired and community-owned initiatives. ${ }^{34}$ On the other hand, as noted above, it has been thanks to the involvement and support of external actors that many LPCs have been able to sustain their activities over an extended period of time. The centrality of external support is underscored by the recent trend in which some LPCs in South Africa and Kenya have opted to transform themselves into NGOs in order to be eligible for donor funding. There is a need for more empirical research to better understand the implications of external support for the autonomy and effectiveness of local peace committees. It is, however, clear from the cases discussed above that LPCs could, at the very least, benefit from some financial, logistical, and technical support. The lingering challenge is how to ensure that external involvement does not compromise their indigenous character.

\section{CONCLUSION}

Grassroots initiatives for peacebuilding and social cohesion have a long history in African societies. However, it was the post-Cold War local orientation in peacebuilding, embodied in the concept of peacebuilding from below, that gave greater prominence to these initiatives within "mainstream" peacebuilding discourses and practices. The prevalence of LPCs as mechanisms for micro-level peacebuilding across the continent should be seen in this context. The experience of three decades of LPCs discussed in this chapter can be summarized in two overarching lessons.

First, the principles of local initiative and local agency that underpin the idea of LPCs are necessary but not sufficient peacebuilding requirements. This is because the local context itself is as much a terrain for the reinforcement of oppressive and violence-breeding tendencies as it is a catalyst 
for building sustainable peace. The fact that LPCs are embedded in these complex local environments presents both opportunities and challenges for peacebuilding.

Second, the effectiveness of LPCs is strengthened when these initiatives are conceived as a complement to broader national, regional, or international peacebuilding processes. Against the backdrop of the complex and multi-level nature of contemporary conflicts, it is naïve to imagine that grassroots initiatives can, on their own, resolve the multiple threats to local peace and social cohesion. In many instances, local conflicts and insecurity are intertwined with national, regional, and even global dynamics so that even with the best of intentions, local actors often lack the authority and capacity to act decisively. This then calls for a collaborative peacebuilding framework that links local, national, regional, as well as global initiatives and resources, although care must be taken to ensure that local agency is not stifled in the process.

\section{Key ReCOMmendations}

1. Create an enabling legal and policy framework for local peace committees. African governments can contribute to creating an enabling environment for local peace committees by putting in place appropriate legal and policy frameworks that clearly define the role and mandate of LPCs in relation to existing peacebuilding and governance institutions. While the formalization of LPCs is not a prerequisite for their effectiveness, and in some instances can even be an impediment, it is still imperative for these structures to be institutionally recognized and protected. This will not only provide institutional support for LPCs, but will also eliminate potential overlap and conflict between LPCs and state institutions. An appropriate legal and policy framework will also help to address the accountability deficit that many LPCs face. This is particularly useful in those countries that are yet to establish a national peace infrastructure.

2. Incorporate local peace committees into all new post-conflict peacebuilding initiatives. Subsequent United Nations (UN) and African Union (AU) post-conflict peacebuilding missions should include a mandate to support and integrate LPCs into their respective national peacebuilding strategies. As observed earlier, local peace committees can be effective mechanisms for localizing national peace efforts. 
Recognizing LPCs as an integral part of the post-conflict peacebuilding frameworks of the $\mathrm{UN}$ and the AU, while also respecting their autonomy and uniqueness, will assure these local structures of the resources as well as the institutional legitimacy and support needed to make a meaningful contribution to the peaceful and sustainable transformation of post-conflict environments in Africa.

3. Establish national and regional networks of local peace committees. International actors like the UN and Western donors can contribute to developing the peacebuilding capacity of local peace committees in Africa by establishing and supporting national and regional networks of LPCs to serve as platforms for facilitated peer learning and support, as well as the sharing of experiences and best practices. These mechanisms can be used to strengthen the capacity and performance of individual LPCs without directly interfering in their operations or making them dependent on outside support.

\section{Notes}

1. Andries Odendaal, "An Architecture for Building Peace at the Local Level: A Comparative Study of Peace Local Committees," UNDP Discussion Paper (December 2010), 7.

2. William Tsuma, Cecile Pentori, and Moe Mashiko, "Local Peace Committees: Building Social Cohesion and Resilience Within the Infrastructure for Peace Framework," Conflict Trends 3 (2014): 49.

3. John Paul Lederach, Building Peace: Sustainable Reconciliation in Divided Societies (Washington, DC: United States Institute of Peace Press, 1997); Elise Boulding, Cultures of Peace: The Hidden Side of History (New York: Syracuse University Press, 2000); and Oliver P. Richmond, A Post-liberal Peace (London: Routledge, 2011).

4. Kaitlyn Hedditch, "It's a Matter of Perspective: Revisiting Kenya's Wajir Peace and Development Committee and Its Contribution to Current Discussions on Infrastructures for Peace," Peace and Conflict Review 9, no. l (2016): 48 .

5. Andries Odendaal, "An Architecture for Building Peace at the Local Level," 40.

6. Hedditch, "It's a Matter of Perspective," 48.

7. Odendaal, "An Architecture for Building Peace at the Local Level," 55; Abdul Karim Issifu, "Local Peace Committees in Africa: The Unseen Role in Conflict Resolution and Peacebuilding," Africology: The Journal of Pan African Studies 9, no. 1 (2016): 152-153. 
8. Rene Claude Niyonkuru, "Building the Peace Architecture from the Bottom-Up: The Experience of Local Peace Committees in Burundi," Occasional Paper: Peacebuilding Series, No.5 (Future Generations Graduate School, November 2012).

9. Andries Odendaal and Chris Spies, "'You Have Opened the Wound, But Not Healed It': The Local Peace Committees of the Western Cape, South Africa," Peace and Conflict: Journal of Peace Psychology 3, no. 3 (1997): 263. See also Willem Ellis, "Infrastructure for Peace (I4P): Relearning the Lessons of the Past," Southern African Peace and Security Blog, February 7, 2016.

10. Odendaal, "An Architecture for Building Peace at the Local Level," 3639; Odendaal and Spies, "You Have Opened the Wound." See also Deji Olukotun, "The Spirit of the National Peace Accord: The Past and Future of Conflict Resolution in South Africa," African Journal of Conflict Resolution 9, no. 1 (2009): 108-109.

11. Phiroshaw Camay and Anne J. Gordon, "The National Peace Accord and Its Structures," https://www.nelsonmandela.org/omalley/index. php/site/q/03lv02424/04lv03275/05lv03294/06lv03321.htm.

12. Odendaal, "An Architecture for Building Peace at the Local Level," 56.

13. See, for example, Oliver Ramsbotham, Tom Woodhouse, and Hugh Miall, Contemporary Conflict Resolution, Third Edition (Cambridge: Polity Press, 2011), 232-245.

14. Balazs Aron Kovacs and Paddy Tobias, "Questioning Peace Infrastructure and Peace Formation," Peace and Conflict Review 9, no. 1 (2016): 2.

15. Andries Odendaal, Local Peace Committees: Some Reflections and Lessons Learned (Kathmandu: Academy for Educational Development, n.d.), 13.

16. Odendaal, "An Architecture for Building Peace at the Local Level," 5556. See also William A. Awinador-Kanyirig, "Ghana's National Peace Council," Global Centre for the Responsibility to Protect, Policy Brief (August 2014).

17. Odendaal, "An Architecture for Building Peace at the Local Level," 41.

18. Louise Khabure, "Committed to Peace or Creating Further Conflict? The Case of Kenya's Local Peacebuilding Committees," Peace Insight, December 10, 2014.

19. Luke Glowacki and Katja Gonic, "Investigating the Potential of Peace Committees in Ethiopia: A Needs Assessment in IGAD CEWARN's Karamoja and Somali Clusters," Report Commissioned by the Ethiopian Conflict Early Warning and Early Response Unit and GIZ (2013).

20. See Niyonkuru, "Building the Peace Architecture from the Bottom-Up."

21. Niyonkuru, "Building the Peace Architecture from the Bottom-Up," 3941.

22. Author conversation with staff at Action Support Centre (October 2016).

23. Author conversation with staff at Action Support Centre. 
24. Author conversation with a member of the Alexandra Local Peace Committee (October 2016). See also Action Support Centre, "Responses to Violence and Looting in SOWETO," February 9, 2015, http://www. asc.org.za/2015/02/09/responses-to-violence-and-looting-in-soweto/.

25. Odendaal, "An Architecture for Building Peace at the Local Level," 3639; Odendaal and Spies, "You Have Opened the Wound." See also Deji Olukotun, "The Spirit of the National Peace Accord: The Past and Future of Conflict Resolution in South Africa," African Journal of Conflict Resolution 9, no. 1 (2009): 108-109.

26. Odendaal, "Local Peace Committees," 13.

27. Author conversation with Refiloe Khunou, Peace Monitor, Alexandra Local Peace Committee, October 2016. See also Action Support Centre, "Responses to Violence and Looting in SOWETO."

28. Odendaal, "An Architecture for Building Peace at the Local Level," 4142.

29. Khabure, "Committed to Peace."

30. Odendaal, "Local Peace Committees," 4.

31. Khadija Patel, "Orange Farm: Community Reconciliation Still a Distant Dream," Daily Maverick, July 20, 2016.

32. Hedditch, "It's a Matter of Perspective," 52.

33. Patel, "Orange Farm."

34. Khabure, "Committed to Peace or Creating Further Conflict?"; See also Odendaal, "Local Peace Committees," 23.

Open Access This chapter is licensed under the terms of the Creative Commons Attribution 4.0 International License (http://creativecommons.org/licenses/ by $/ 4.0 /$ ), which permits use, sharing, adaptation, distribution and reproduction in any medium or format, as long as you give appropriate credit to the original author(s) and the source, provide a link to the Creative Commons license and indicate if changes were made.

The images or other third party material in this chapter are included in the chapter's Creative Commons license, unless indicated otherwise in a credit line to the material. If material is not included in the chapter's Creative Commons license and your intended use is not permitted by statutory regulation or exceeds the permitted use, you will need to obtain permission directly from the copyright holder.

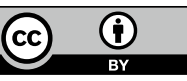

